\title{
PARTICIPATION TO EMPOWER CHILDREN AND STRENGTHEN THE COMMUNITY
}

\author{
Sabina Langer \\ Free University of Bolzano/Bozen (Italy)
}

\begin{abstract}
In a pandemic, children's participation is even more important than before. This paper presents the first stage of an exploratory study for my $\mathrm{PhD}$ research in Pedagogy beginning in January 2021 in Milan.

The participants are 19 pupils of class 4B (primary school), their parents and the teachers who joined energies to reproject a square, in order to transform it into a welcoming space for the entire community. In Italy, public speeches did not mention children who could not finally use public spaces for months as they were identified as the "plague spreaders".

The project revisits this perspective by considering children as potential actors of the transformation. Only if adults set the conditions for a change, children, their needs and their imagination could become agents for that change and centre of the community. The project name is Piazziamoci (Let's place ourselves here) to signify the conscious act of taking a place together.

After a theoretical framework of the study within Student Voice, I describe the generative circumstances, the context and the first steps of the project. The children explored the square, interviewed the inhabitants, shared information and dreams with their classmates coming up with proposals to present to City Council. This first phase aimed to set the basis of my investigation on the participants self-awareness as people and members of the community; it also focuses on the perception of the square as a common good. To this purpose, this work introduces concepts as the capacity to aspire (Appadurai, 2004), imagination and creativity (Vygotsky, 1930/2004), interdependence (Butler, 2020), and, therefore, a political and educational interpretation of the project.

Imagine a city where there is no desire. A city without desire is a city of no imagination. Here people think only what they already know. Anne Carson, Eros the bittersweet (Normal, IL, Dalkey Archive Press, 1988, p.168).
\end{abstract}

Keywords: Participation, imagination, community, empowerment, common good.

\section{Introduction}

This paper presents the first stage of an exploratory study for my $\mathrm{PhD}$ research in Pedagogy. After outlining the theoretical framework within Student Voice, it describes the context and the first steps of the project Piazziamoci (Let's place ourselves here) begun in January 2021 in Milan. The participants are 19 pupils of class $4 \mathrm{~B}$ (primary school), their parents and their teachers who joined energies to reproject a square, in order to transform it into a welcoming space for the entire community. This first stage aimed to set the basis for investigating if the participants are about to become aware of themselves as people and members of the community and if they are about to perceive the square as a common good.

\subsection{The right to participate: The context of the exploratory study}

The exploratory study can be framed within Student Voice, that emerged in the 1990s in the English-speaking world: "Authorising student perspectives means ensuring that there are legitimate and valued spaces within which students can speak, re-tuning our ears so that we can hear what they say, and redirecting our actions in response to what we hear" (Cook-Sather, 2002, p. 4). The Student Voice approach starts listening and involving students to change all those issues that affect them. Over time, two main currents took shape, both followed by a large number of researchers: the first starts with Jane Rudduck (2004) and focuses on teaching/learning processes; the second, outlined by Fielding (1999, 2001, 2012), deals with more political topics (democracy, power, participation) and is based on the empowerment of students as people. 
Levin (2000) identified reasons for including students in the processes of rethinking places and institutions, which are still very relevant in Italy:

"1. Effective implementation of change requires participation by and from all those involved, students no less than teachers; 2 . Students have unique knowledge and perspectives that can make reform efforts more successful and improve their implementation; 3. Students' views can help mobilise staff and parent opinion in favour of meaningful reform; 4. Constructivist learning, which is increasingly important to high standards reforms, requires a more active student role in schooling; 5. Students are the producers of school outcomes, so their involvement is fundamental to all improvement." (Levin, 2000, pp. 156-157).

In Italy, some meaningful research on Student Voice was carried out and collected in a volume by Grion \& Cook-Sather's (2013). This publication also contains an important article arguing on the concordance of this approach with the Italian National Guidelines for the school (Grion, 2013). The Student Voice studies and experiences highlight a better relational and learning environment in schools where active participation is encouraged. The project Piazziamoci develops both aspects, the political and the learning/teaching one; nevertheless, this paper does not deal with the interdisciplinary part of the project. Besides the transformative aim, the project has an educational and political purpose to empower children as active participants in the community: pupils learn to connect different "spaces" (the classroom, the square) and people (classmates, teachers, parents, inhabitants of the square). Although political participation skills do not belong to the standard school curriculum, they are among the most important acquisitions everyone should achieve (Levin, 2000).

This first stage aimed to set the basis for my research. During the first lockdown due to the Covid19, in spring 2020 in Italy, children were not mentioned in public discourses and could not leave their homes, identified as "plague spreaders". This unusual situation, in which children were forgotten (Novara, 2020), fits in the Italian educational context. Despite article 12 of the UN Convention on the Rights of the Child (1989), assuring children the right to express themselves freely in all matters affecting them, the participation of children and young people is still neither frequent nor encouraged.

Concerning the ongoing studied project started in Milan (Italy) in January 2021, the first phase described in this paper, had to stop at the beginning of March with the second lockdown and the closure of schools.

Against the Italian trend, in the project, children have space for action and operational autonomy (Lansdown, 2001) to become radical agents of change (Fielding, 2001). While adults are supporters, preparing the preconditions for action: children, their needs and imagination are put at the centre of the community. The name of the project is Piazziamoci (Let's place ourselves here) to signify the conscious act of taking a place together.

The project Piazziamoci is embedded in peculiar generative circumstances. Ms G., the main teacher, and more than half of the parents were trained in nonviolent practices and strategies for three years by ED.UMA.NA (www.edumana.it), a network promoting nonviolent education and practices to empower the school community. Ms G. has also been working for years to increase children participation. For these reasons, she decided to partake in a call of the City Council, which invited schools to develop projects involving pupils to take care of their surroundings. She was aware that such a project could have brought empowerment and well-being to the pupils and the class. Hence, in December 2020, Ms G. made arrangements with the City Council and an ED.UMA.NA tutor started helping her to involve the parents in the project. Parents were happy to participate actively. Another important occurrence is the habit of this class to have an "agora" every morning: the pupils sit in a circle and discuss some relevant issues among them and with their teacher. In times of pandemic, it is harder to have the agora as it is not allowed to sit close to each other. However, class 4B did not suspend this practice. It is considered important for learning to speak, express feelings and emotions, and listen to others. Therefore, they still have the agora sitting at their desk respecting the safety rules.

\section{The first steps of Piazziamoci}

Piazziamoci is an exploratory study for my ongoing PhD. The goal is to verify if, through participation: (1) children and adults will become aware of themselves as people (empowerment) and as members of the community and (2) participants will perceive the square as a common good and develop empathy with the territory. I will conduct a relevant number of interviews, groups of discussion and questionnaires with the involved participants.

Through data triangulation, I will get to the results of the investigation and see if a transformative and generative process took place. The main idea grounding the investigation relies on Appadurai's assumption that culture cannot be understood just as origins, past, or identity. Rather, the concept must include possible futures, desires, reasons and share these aspirations. Girls and boys who 
dream and reproject a square, a public space, thus represent the "capacity to aspire", a fundamental human ability, a cultural capacity and a measure of democratic evaluation (Appadurai, 2004).

In this paper, I describe the first stage of the project according to the data collected during my participation in public actions and the frequent planning-meetings with the teachers, the coding of the materials produced by pupils, a first exploratory questionnaire made for children and for/ parents and an in-depth interview with each teacher.

January and February 2021 were essential months for the foundations of Piazziamoci, turning the dream into a concrete project for the square, although the main teacher, Ms G. got injured in January and left the class to Ms M., a teacher-in-training.

During an agora the project started: at the beginning, each child imagined the square as they would like it to be. By probing their desires and sharing them with peers, they began the creative process. These first inputs were collected in a single "dream-square" containing: swings, ramps for skates, flowery lawns and big trees, tables for playing chess, designs on the floor to make it colourful, goal doors and baskets for playing football and basketball, a maze, an outdoor library, a fountain, a stage for performances, a treehouse... As the square is a common good and should be perceived like that, it was decided to gather the opinion of the other people who use it. Together with Ms M., the pupils structured an interview. Together with the parents, children went in small groups to the square and collected information from its inhabitants. The following days, they worked to design the square, considering their wishes and what emerged from the interviews. Children worked in cooperative learning, a method they use since first grade, to plan how they would like the square to be. They also built three-dimensional models with cardboard, paint, scissors and glue. Metacognitive work in this first phase included two moments in mid-February. Documentation is also a citizenship practice that supports the educational and learning process. In order to belong to a wider community than the classroom, it is crucial to give visibility to what is done at school, shown, and be seen. In collective writing, inspired by the practices of Mario Lodi (1970/2014), children wrote an article for the neighbourhood newspaper describing their project. The second "public" moment was the presentation of the project to the City Council. With the support of the teacher, the pupils prepared slides for the presentation of Piazziamoci, combining texts and photographs. The representatives of the Girls and Boys Council introduced the collective work at the online City Council meeting. On that occasion, the President of the City Council recalled the importance of considering the market, which is held twice a week on the square; therefore, the square cannot have stable games and equipment everywhere. To adjust the ideas for the square and make them feasible, the ED.UMA.NA tutor called children and parents to an agora in the square. Maieutic questions stimulated their imagination. A new plan started to be developed: boys and girls decided to set in the smaller area allowed colourful benches, tables for homework, playing chess, relaxing corners. In the rest of the square, they would like to have an enormous drawing to use as a track for bicycles, skates, skateboards and scooters. The design should be a city within a city (houses, school, supermarket, park) then becoming countryside, sea, mountains, savannah, jungle, sky. At the beginning of March, a new lockdown and the following school closures interrupted the project, which started again in the middle of April, while I am writing this paper. For the children of class $4 \mathrm{~B}$ something already changed: now they are the ones who use the huge grey square to play and spend time together. Slowly the square will be filled with children and colours.

\section{Imagining together to become citizens and community}

A square, as well as an agora, are common spaces. The pupils of class 4B are used to have an agora every morning. When the Ancient Greeks founded a new city, they left an empty space in the middle of it: the agora, the square. From this unique space, the Greeks started democracy. Like the agora in the classroom, the town square is a collective area, a place for relationships where people can play, discuss, share ideas, opinions and meet. Both are places of social aggregation, knowledge and exchange. The square can become a place of conviviality (Illich, 1973/1974), where everyone brings and finds something of themselves and shares it with others. For this reason, working on the project Piazziamoci has a strong symbolical meaning that makes it possible to consider imagination and creativity as political and citizenship skills. As already affirmed by many pedagogies since Dewey (1916/1995), the community has a fundamental role in education. The social and cultural environment determines the capacity of each person to take place and voice as well as the capacity to imagine a different future, the capacity to aspire (Appadurai, 2004). One issue of investigation in this first phase is the role of imagination, as the following data show. 
Boy: "I really enjoyed making the model of the square because there was much space for imagination."

Mother: "They learn to put ideas together to create spaces they have imagined themselves."

Teacher: "Imagination was the engine that lit the fire and then the glue for everything. [...] I think it is important, especially for children, to imagine something beautiful for themselves and others, and I mean for everyone."

The collected data suggest the importance of imagination at this early stage of the project. Quoting Vygotsky, "it is precisely the human creative activity that makes the human being a creature oriented toward the future, creating the future and thus altering his own present." (Vygotsky, 1930/2004, p. 3). To Vygotsky, creativity is not simply the recollection of lived impressions but a creative re-elaboration, a process through which the child combines experiences and constructs a new reality, responding to its needs and curiosities. The creative activity of imagination depends on the social environment, the richness and variety of the individual previous experience. This experience provides the material from which the constructions of the imagination are made. "Every inventor, even a genius, is also a product of his time and his environment." (Vygotsky, 1930/2004, p. 24).

Another issue of my investigation was about active citizenship, especially concerning the openness towards the territory. According to the collected data, the interviews with the inhabitants of the square seemed to be an important opportunity for interaction and growth. Preparing such an interview is a big step of citizenship. It means opening up to the world, leaving the safe community of the classroom and seeing ourselves as citizens and members of a larger community. It activates curiosity for the unfamiliar, widening our thinking to include the needs of others. In fact, some children were initially scared about the idea of talking to strangers ("What if I'm not able to ask questions? What if someone does not answer me?"). After talking wildly in class, they were reassured and understood the importance of overcoming fear for considering the voice of others.

Ms M. said in the interview: "Children are aware that this will not be just their square but everyone's square and the fact that they thought about it, about who attend high school, the shopkeepers, about grandparents with grandchildren and dogs, is a fundamental skill of citizenship. They did not think of a square tailored for the class $4 \mathrm{~B}$, but of a square that is for everyone, beautiful for everyone."

The first collected data seem also to show that the pandemic has changed the meaning of the square for teachers and parents. It has become a space in which it is possible to be together in safety, a place to use more and more, somewhere to change in order to make it more "of us". Concerning the question on the meaning of the project Piazziamoci, parents answered: "It is a good exercise in planning and active citizenship"; "It is an opportunity to give the community a voice to decide on the spaces that belong to us"; "A way to bring children closer to institutions and the common good"; "An opportunity to experience a sense of civic community, democracy and an exchange of ideas"; "Meaningful, doing something positive with my son and feeling part of the community".

It is possible to use Judith Butler's (2020) concept of 'interdependence' in which she proposes an anti-individualistic and nonviolent approach and states that everyone is always involved in the lives of others. No person stands alone at any time in life; on the contrary, everybody is always related to society and the environment. Violence against others means, therefore, violence against oneself because violence attacks the interdependence of the living (Butler, 2020). From this perspective, Piazziamoci may counteract the situation of isolation created by the pandemic, which has deprived everyone, especially children and young people, of community life and life outside their home. Participants seem to be aware of it. Furthermore, they feel the opportunity to rediscover an intentional public space and enjoy common planning. In this perspective, the square could become a convivial tool (Illich, 1973/1974), i.e., a space that can be mastered and used together with the community, in contrast to what normally happens, where the tool dominates and shapes human action.

\section{Conclusion}

In this first stage, I tried to lay the foundations of this study to observe if Piazziamoci impacted the participants in terms of self-awareness as members of the community and their perception of the square as a common good. Therefore, the interpretation I propose of this participatory action is educational and political because it concerns the building of meaningful experiences in that space between people. The space that is possible in relationships, the space that allows the creation of something new: the act of imagining together becomes a political act. Today, in times of pandemic, we need a new collective imaginary starting from interdependence to help children finding their place in the world. 


\section{References}

Appadurai, A. (2004). The Capacity to Aspire: Culture and the Terms of Recognition. In V. Rao \& M. Walton (Eds.), Culture and Public Action (59-84). Stanford: Stanford University Press.

Butler, J. (2020). La forza della nonviolenza: Un vincolo etico politico. Milano: nottetempo. (Original work published 2020)

Dewey J. (1995). Democrazia e educazione. Firenze: Nuova Italia. (Original work published 1916)

Fielding, M. (1999). Radical collegiality: Affirming teaching as an inclusive professional practice. Australian Educational Researcher, 26, 1-34.

Fielding, M. (2001). Students as radical agents of change. Journal of Educational Change, 2, 123-141.

Fielding, M. (2012). Beyond Student Voice: Patterns of partnership and the demands of deep democracy. Revista de Educación, 359, 45-65.

Grion V. \& Cook-Sather A. (Eds.). (2013). Student Voice. Prospettive internazionali e pratiche emergenti in Italia. Milano: Guerini Scientifica.

Grion, V. (2013). Partecipazione e responsabilità nelle indicazioni nazionali per il curricolo del primo ciclo di istruzione. In V. Grion \& A. Cook-Sather (Eds.), Student Voice. Prospettive internazionali e pratiche emergenti in Italia (pp. 136-152). Milano: Guerini Scientifica.

Illich, I. (1974). Convivialità. Milano: Mondadori. (Original work published 1973)

Lansdown G. (2001). Promoting Children's Participation in democratic decision making. Firenze: Unicef Innocenti Research Centre.

Levin B. (2000). Putting Students at the Centre in Education Reform. Journal of Educational Change, 1, $155-172$.

Lodi M. (2014). Il paese sbagliato. Diario di un'esperienza didattica. Torino: Einaudi. (Original work published 1970)

Novara, D. (2020). I bambini sono sempre gli ultimi. Come le istituzioni si stanno dimenticando del nostro futuro. Milano: BUR Rizzoli.

Rudduck, J. (2004). Pupil voice is here to stay! University of Cambridge: QCA Futures.

Vygotsky L. (2004). Imagination and Creativity in Childhood. Journal of Russian and East European Psychology, 42 (1), 7-97. (Original work published 1930) 